\title{
Development of a colorimetric loop-mediated isothermal amplification diagnostic assay for deer tick virus
}

${ }^{1}$ Biochemistry and Molecular Biology, Lebanon Valley College, 101 North College Ave, Annville, PA 17003.

${ }^{2}$ Biology Department, Millersville University, 40 Dilworth Road, Millersville, PA 17551.

*To whom correspondence should be addressed: eric.ryndock@ millersville.edu (Eric J. Ryndock)

Abstract: Deer tick virus (DTV) is an emerging pathogen in North America. This virus can cause nervous system complications such as encephalitis in humans. Further, no data has been surmounted around long-term effects of infection from DTV patients across variable age groups. Diagnostic tools of DTV used by government laboratories are based on RT-PCR using patient serum or ticks. This paper explores the feasibility of a colorimetric loop-mediated isothermal amplification (LAMP) assay to create a point-of-care diagnostic methodology for use in field and in primary care. LAMP consists of six primers that bind to target DNA and amplifies variable length nucleotide strands that can be visualized through side reactions or via electrophoresis. First, a viable LAMP primer set, and a primer set that dimerizes and amplifies DNA regardless of compatibility were created in silico and validated in vitro. Then, a specific LAMP assay was developed. Our findings showed this method can be performed within 30 minutes and can measure with limits of detection comparable to PCR.

\section{Introduction}

Deer tick virus (DTV) has a positive-sense, single-stranded RNA genome and belongs to the genus Flavivirus in the family Flaviviridae. Other members of this virus genus and family are dengue virus, 
medRxiv preprint doi: https://doi.org/10.1101/2020.08.24.20181248; this version posted January 11, 2021. The copyright holder for this preprint (which was not certified by peer review) is the author/funder, who has granted medRxiv a license to display the preprint in perpetuity. It is made available under a CC-BY-NC-ND 4.0 International license.

Zika virus and West Nile virus. The genome length of DTV is roughly 10,800 bases and it known to cause tick-bourne encephalitis (Artsob et al. 2001).

It is common that members of Flaviviridae are vectored through arthropods such as mosquitoes and ticks. The increasing presence of DTV throughout North America is coupled with various tick species (CDC 2019). DTV is also referred to as the second lineage Powassan virus (POW2), deviating from a native strain in Europe and Russia. POW1, or Powassan virus lineage I, has a variable genetic diversity along the theoretical divergence cutoff at $84 \%$ nucleotide identity to DTV, 94\% amino acid identity, and is estimated to have diverged around 200 years ago (Pesko et al. 2010). This cutoff provided the difference between the two Powassan viruses on the cladogram of Flaviviridae (Telford III 1997). Patient testing for DTV is usually performed in response to severe cases where symptoms arrive suddenly. Most people tested for DTV have symptoms of acute encephalitis or overactive inflammation of the brain, which leads to death in some cases without proper medical treatment (Tavakoli et al. 2009; Solomon et al. 2018). Remaining cases go unbeknownst because testing measures are not approached from typical or asymptomatic standpoints as other tick-borne infections. Current diagnostic testing is limited to the Center of Disease Control and its partnering laboratories using either reverse transcription-polymerase chain reaction (RT-PCR) or immunohistochemical techniques (Morozova et al. 2002; CDC 2019). A sample of serum or cerebral spinal fluid is collected and sent to one of the offsite diagnostic centers, further complicating the testing process and taking up to a few days for results to become available.

A more time effective detection method than RT-PCR would be beneficial for point-of-care testing (POCT), as well as for field surveys of tick samples that are performed by state game commissions. Three different species of ticks, i.e., Ixodes cookie, Ixodes marxi, and Ixodes scapularis, have the potential to transmit DTV from their main vertebrate hosts, i.e., woodchucks, squirrels, and white-footed mice, to humans (Brackney et al. 2010). The white-tailed deer, Odocoileus virginianus, is also a known host to Ixodes scapularis. DTV has no known pathology on these intermediate mammal hosts, but there is increasing concern towards human infection occurrence (CDC, 2019). The main tick vector that raises 
medRxiv preprint doi: https://doi.org/10.1101/2020.08.24.20181248; this version posted January 11, 2021. The copyright holder for this preprint (which was not certified by peer review) is the author/funder, who has granted medRxiv a license to display the preprint in perpetuity.

It is made available under a CC-BY-NC-ND 4.0 International license.

human concern is Ixodes scapularis. This tick species has a parasitic relationship with white-tailed deer and other species of deer that humans encounter frequently in rural areas (Brackney et al. 2010). This host relationship is unique to DTV and unlike the previously mentioned POW1 strain. The prevalence of outdoor recreation and leisure activities give exposure to the tick vectors and potential pathogens to be transmitted.

Monitoring the presence of DTV provides the first steps to surveying disease spread and to developing mitigation efforts. A rapid DTV detection assay like colorimetric loop-mediated isothermal amplification (LAMP) would prove useful for field surveys and POCT. LAMP is an alternative nucleic acid amplification technique that has gained popularity in the past decade (Tomlinson 2008; Luo et al. 2011; Chen et al. 2014; Lau et al. 2015; Lamb et al. 2018; Shin et al. 2018; Anupama et al. 2019). LAMP is a nucleotide amplification process that occurs through the binding of specially designed primers at approximately $60^{\circ} \mathrm{C}$ that generates variable ladder structures that can be visualized in two manners. Colorimetric LAMP does not require expensive and sophisticated equipment or visualization techniques other than the naked eye. Additional variants of LAMP assays, such as RT-LAMP, have surmounted for the specific detection of RNA as opposed to cDNA which was utilized in this report (Chen et al. 2014). In addition, LAMP is inexpensive and quick. For example, the Colorimetric Warmstart® MasterMix (New England Biolabs, Cat\# M1800S) LAMP technique, utilized in this paper, is up to five times quicker than PCR and changes color for visual assessment of the results (Nagamine et al. 2002). The colorimetric test starts out as pink and turns a bright yellow color if the result is positive. Color change is dependent on the release of protons through nucleotide assimilation on target DNA (Mitra et al. 2019). The amplified DNA can then be confirmed through electrophoresis on an agarose gel followed by staining with ethidium bromide or Coomassie Blue ${ }^{\circledR}$ to display banding, validating the presence of DTV in the tick sample tested. Additional efforts have been made available to educate and summarize LAMP technology in recent literature (Becherer et al. 2020; Roy et al. 2020). In this paper we present our preliminary data on 
medRxiv preprint doi: https://doi.org/10.1101/2020.08.24.20181248; this version posted January 11, 2021. The copyright holder for this preprint (which was not certified by peer review) is the author/funder, who has granted medRxiv a license to display the preprint in perpetuity.

It is made available under a CC-BY-NC-ND 4.0 International license .

the development of a colorimetric LAMP detection of DTV and discuss perspectives of our research for POCT.

\section{Materials and Methods}

Nucleotide sequence analysis and homology analysis for DTV strains

The greatest amount of genetic variance between strains of DTV were estimated through a maximum composite likelihood analysis method. The greatest amount of conservation was determined to be at the RNA-dependent RNA Polymerase (RdRp) coding site using the codon based Z-test. Two bioinformatics methods, i.e., the codon-based Z-test, and the Neighbor-joining phylogenetic tree method, were used to analyze the RdRp coding region or full DTV genome to determine nucleotide sequence conservation. Phylogenetic analyses were performed using the software suite MEGA7: Molecular Evolutionary Genetic Analysis version 7.0 (Kumar et al., 2015) using 22 DTV accessions retrieved from GenBank, an opensource genetic sequence database hosted by the National Institute of Health.

\section{Codon based Z-Test}

Alignment tools were utilized to investigate the homology between the conserved sequences of DTV. Positive selection for the resistance to mutation was analyzed through the codon-based Z-test as defined by Equation 1. When analyzing the homology, the null hypothesis is regarded such that the sequences are not similar and only by rejecting the null hypothesis when $p<0.05$, can we assume that the sequences are considered homologous. The analysis used four different sequences found in the United States with variable accession ID prefixes to provide additional variability to the analysis.

$$
\mathrm{Z}=\frac{d \mathrm{~N}-d \mathrm{~S}}{\sqrt{(\operatorname{Var}(d \mathrm{~S})-\operatorname{Var}(d \mathrm{~N}))}}
$$

Equation 1. The Z-test for codon homology testing across multiple DTV genomes. Variables denoted in the equation are defined as the number of nonsynonymous substitutions per nonsynonymous site $(\mathrm{dN})$, number of 
medRxiv preprint doi: https://doi.org/10.1101/2020.08.24.20181248; this version posted January 11, 2021. The copyright holder for this preprint (which was not certified by peer review) is the author/funder, who has granted medRxiv a license to display the preprint in perpetuity. It is made available under a CC-BY-NC-ND 4.0 International license.

98 synonymous substitutions per synonymous site (dS), and the respective variances of these variables (Var(dN) and $99 \operatorname{Var}(\mathrm{dS}))$. 
medRxiv preprint doi: https://doi.org/10.1101/2020.08.24.20181248; this version posted January 11, 2021. The copyright holder for this preprint (which was not certified by peer review) is the author/funder, who has granted medRxiv a license to display the preprint in perpetuity.

It is made available under a CC-BY-NC-ND 4.0 International license .

\section{Primer design}

Primers for the LAMP assay were designed through the PrimerExplorerV5 LAMP Primer Designer using the following criteria: (1) genomic regions with a GC ratio of 50-60\%, (2) no more than four successive G's or C's to prevent primers from binding too tightly to the target DNA strand, and (3) stability of F3 and B3 primer ends be lower than -4.00 to create the most stable 5' and 3' loop structures for LAMP proliferation (Wang et al. 2015). The region of the viral genome that was selected for primer design was NS5a that codes the non-structural polymerase.

\section{Primer constructs}

Two primer constructs are evaluated in this paper (Table 1 and Table 2).

LAMP primers were determined using the PrimerExplorerV5 software and the AF311056.1 DTV accession (Kuno et al., 2001). The following primers have been designed using the PrimerExplorerV5 software and have been experimentally tested in the laboratory. Primer set candidates 1 and 2 are displayed with length and position on accession sequence in Tables 1 and 2, respectively. Four primers were designed within the first iteration of software for binding to a target sequence. Figure 1 panel A depicts the amplification process that occurs to create the loop products generated by Bst polymerase. The inner primers denoted Forward Inner Primer (FIP) and Backward Inner Primer (BIP) are the central component of amplification and loop structure formation. Two additional primers $\mathrm{F} 3$ and $\mathrm{B} 3$, complementary to $\mathrm{F} 3 \mathrm{c}$ and $\mathrm{B} 3 \mathrm{c}$ respectively, can bind to the target DNA and displace the amplification product. This allows a repetitive, rapid amplification process. The final two primers Loop Front (LF) and Loop Back (LB) are not pictured in Figure 1 but are able to further amplify and accelerate the loop creation process by providing templates. The reaction is still possible without LF and LB, but a greater limit of detection can be achieved using loop primers. The constructs for LF and LB were generated by inserting the initial primer file into the PrimerExplorerV5 software and following the same protocol. 
medRxiv preprint doi: https://doi.org/10.1101/2020.08.24.20181248; this version posted January 11, 2021. The copyright holder for this preprint (which was not certified by peer review) is the author/funder, who has granted medRxiv a license to display the preprint in perpetuity. It is made available under a CC-BY-NC-ND 4.0 International license.
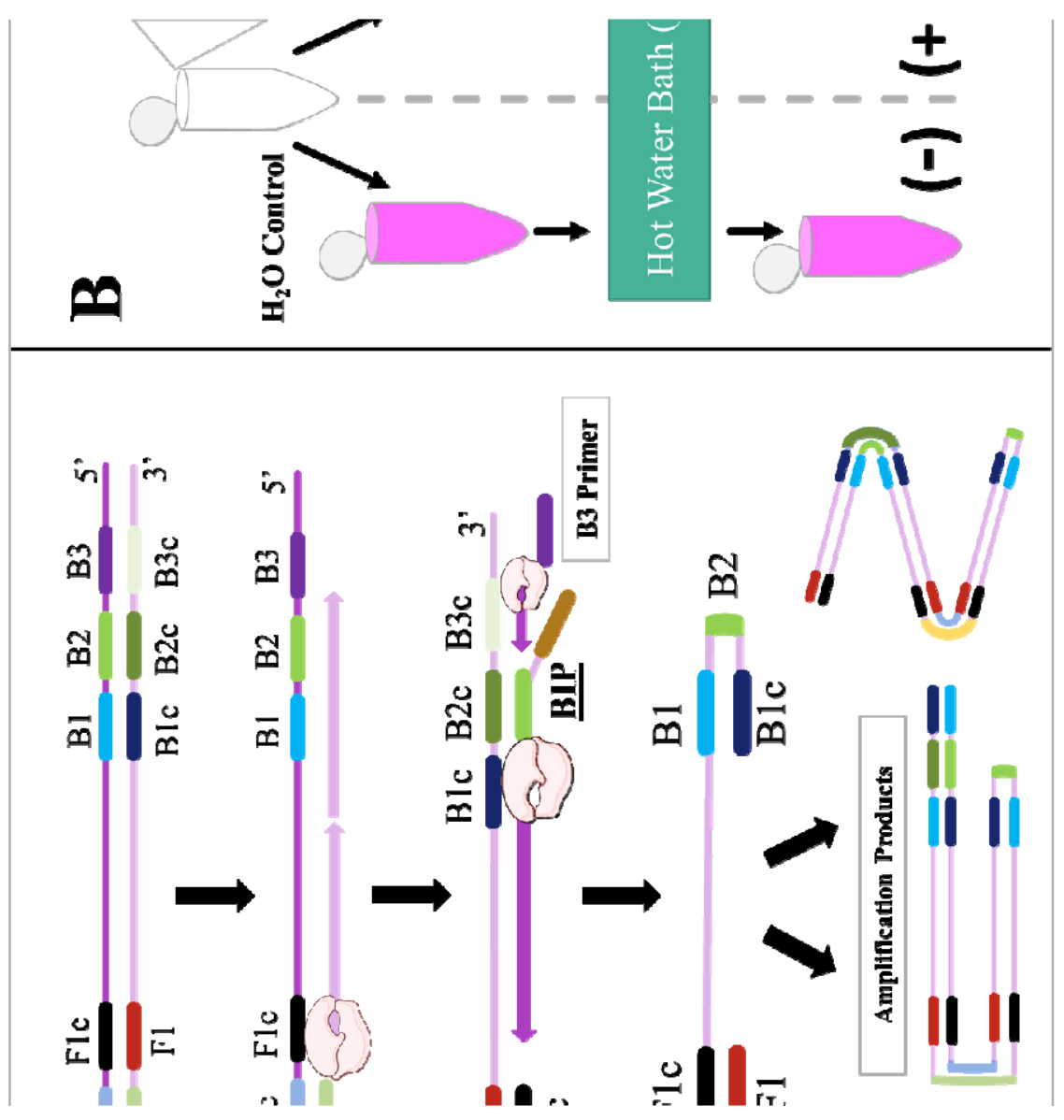
medRxiv preprint doi: https://doi.org/10.1101/2020.08.24.20181248; this version posted January 11, 2021. The copyright holder for this preprint (which was not certified by peer review) is the author/funder, who has granted medRxiv a license to display the preprint in perpetuity.

It is made available under a CC-BY-NC-ND 4.0 International license .

Figure 1. (A) General schematic of LAMP proliferation into ladder structures. Each vertical black arrow indicates a new step of the process for amplification. Three prime and five prime ends are indicated on each side of the strands of DNA as well as the LAMP products. Pink and purple horizontally positioned arrows indicate polymerase activity and are shown in conjunction with the polymerase structure. The initial double stranded DNA is representative of the target DNA cloned into a plasmid. F1, F2, and F3 represent the forward primer sequences and are contained within the FIP, F3, and LF primers. F1c, F2c, and $\mathrm{F} 3 \mathrm{c}$ represent coding sequences of target DNA. This same principle applies to the B1, B2, B3, B1c, B2c, B3c, BIP and LB sequences in a similar manner to create the end loop product of LAMP. Continual amplification events result in variable ladder structures as depicted. (B) General reaction scheme for a colorimetric LAMP assay. Reagents are listed outside first reaction vessel (top) and diverge based on using either $1 \mu \mathrm{L}$ of experimental sample or water control. The results from this procedure include the stagnant pink color for the negative control, and either a color change to yellow, indicating a positive result, or remain pink indicating a negative result for the experimental DNA.

\section{Loop-Mediated Isothermal Amplification (LAMP)}

For the purposes of this experimentation, the optimal temperature for primer candidate 1 was determined to be $59.3^{\circ} \mathrm{C}$ and the optimal time was twenty minutes. The Colorimetric Warmstart@ MasterMix (New England Biolabs) contains nucleotides, Bst polymerase, $16.0 \mathrm{mM}$ Magnesium Sulfate, and $\mathrm{pH}$ sensitive indicator phenol red. The general reaction scheme for colorimetric based LAMP assays is seen in Figure 1

panel B. After the addition of genetic material and molecular grade water to Warmstart ${ }^{\circledR}$ (Table 3), the reaction will proceed in either a hot water bath or a thermocycler held at constant temperature. Results are visualized by the naked eye to be pink (negative) or yellow (positive).

\section{Transformation and purification of plasmid DNA}

A plasmid was created (GenScript) containing a 500 bp synthetic region of DTV's RdRp, with flanking EcoRI and XhoI restriction enzyme sites. The plasmid was transformed into DH5 $\alpha$ chemically competent E. coli for 2 minutes at $37^{\circ} \mathrm{C}$ and plated on nutrient agar plates containing ampicillin. DNA stocks were harvested from single clones by plasmid miniprep kits (Qiagen). The desired cDNA was digested from the vector by EcoRI and XhoI, run on an agarose gel, and purified from the gel with a gel extraction kit (Qiagen). The cDNA from this purification process was used for the experimentation as the DTV RdRp coding strand sample. 


\section{Discussion}

155 From the analysis methods, we concluded that these sequences are statistically significant $(p<0.05)$ to

156 move forward with the RdRp targeted primer design. A 2,000 base-pair sequence was chosen from the

157 DTV NS5a coding region GenBank accession AF311056.1, which includes the coding region for the

158 RdRp. The codon-based test resulted in rejecting the null hypothesis for comparing the four different

159 accessions, with $p<0.05$ for each entry (Table 4). These four accessions represent four divergent strains

160 within the United States and contain great nucleotide conservation. An evolutionary analysis showed the

161 branching of 22 accessions from GenBank including complete genomes and independent RdRp sequences

162 and is visualized in Figure 2. Alignment was performed against the full genome to match the RdRp

163 sequences. The maximum divergence was minimal across all accessions, and primer development was

164 focused in an appropriate area of the DTV genome.

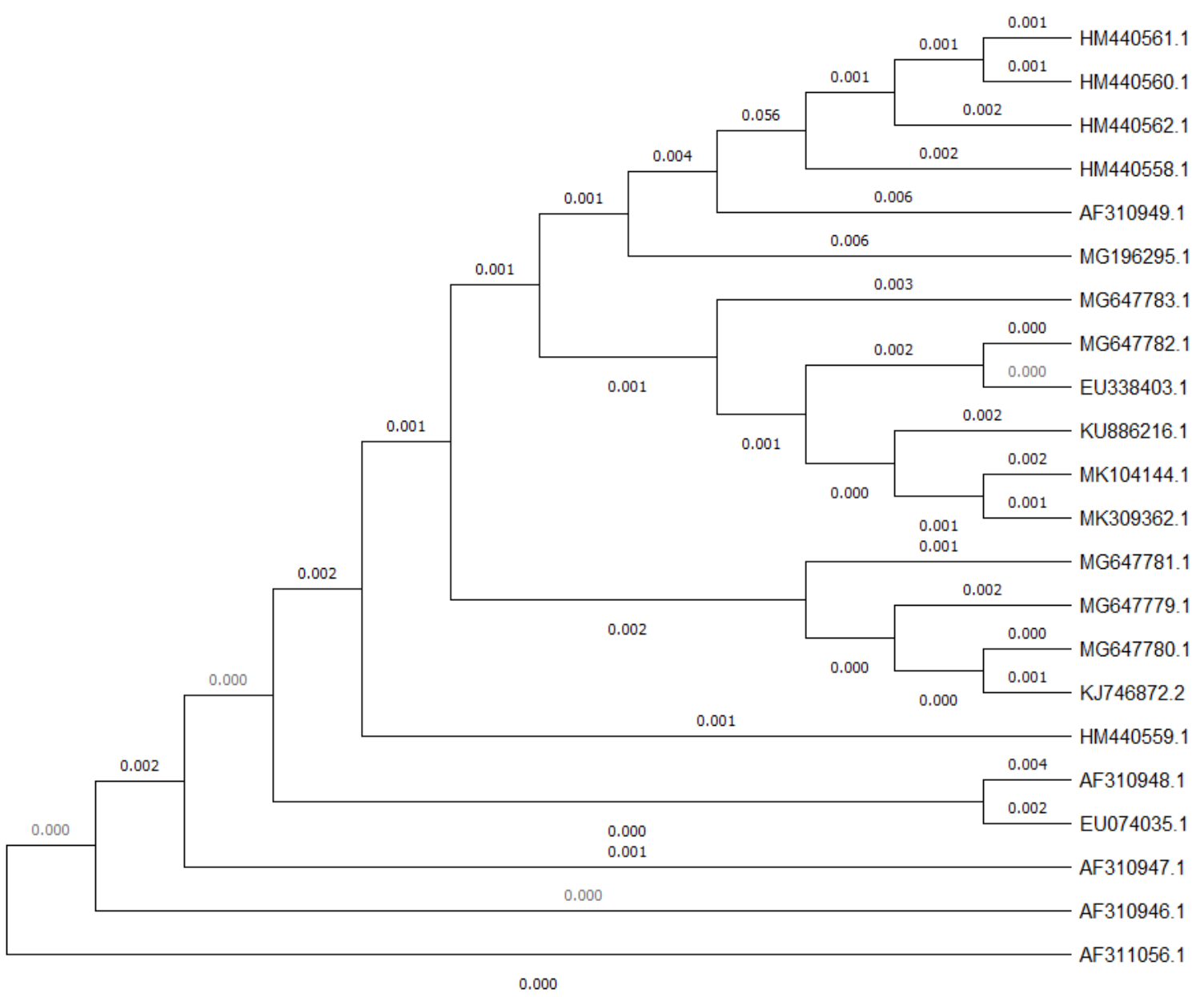


medRxiv preprint doi: https://doi.org/10.1101/2020.08.24.20181248; this version posted January 11, 2021. The copyright holder for this preprint (which was not certified by peer review) is the author/funder, who has granted medRxiv a license to display the preprint in perpetuity.

It is made available under a CC-BY-NC-ND 4.0 International license .

Figure 2. Evolutionary Relationships of Powassan Virus Lineage II, Deer Tick Virus. The evolutionary history was inferred using the Maximum Likelihood method and Tamura-Nei model (Tamura et al. 1993, Felsenstein et al. 1985). The tree with the highest log likelihood (-20885.61) is shown. The tree is drawn to scale, with branch lengths in the same units as those of the evolutionary distances used to infer the phylogenetic tree. Initial tree(s) for the heuristic search were obtained automatically by applying Neighbor-Join and BioNJ algorithms to a matrix of pairwise distances estimated using the Tamura-Nei model, and then selecting the topology with superior log likelihood value (Felsenstein J. 1985). This analysis involved 22 nucleotide sequences and consisted of 1000 bootstrap replications. There was a total of 10843 positions in the final dataset. Evolutionary analyses were conducted in MEGA X (Kumar et al. 2018).

Primer candidate 1 displayed potential and consistency within LAMP assays. Dimerization events were unlikely to occur and provided consistent results. Figure 3 displays typical results from our selected primer sets. When LAMP is run with these primers, a colorimetric change is visualized, and the corresponding products are visualized following electrophoresis on an agarose gel. Controls of nonspecific DNA and water provide negative results as expected. These are desirable traits with LAMP primers to avoid false positives or false negatives. Additional primer sets were designed to confirm our design strategies. The optimal temperature at which this primer candidate function was $59.3^{\circ} \mathrm{C}$ (Figure 3.D).

The second primer set displayed dimerization concerns after looking closely at the dimerization rate of the 5' end of the F3 primer. This observation was denoted after consistent false positives were obtained with primer candidate 2 . The instability of these primers was directly correlated to the instability of the F3 primer being more positive than $\mathrm{dG}=-4.00$ (Table 2 ). This observation can be regarded as a learning guide for future primer design experimentation and allowed for a consistency check with the first iteration generated.

RNA was generated from cDNA using a HiScribe T7 Quick High Yield RNA Synthesis Kit (New England Biolabs \#E2050S) and resulted in similar amplification results as discussed (data not shown). With some variability of these primer sets, it would be better to investigate additional primer candidates before comparing in RNA-doped tick lyase or serum samples. LAMP technology has shown effective detection for both DNA and RNA material and would be simple to implement even for ssRNA viruses 
medRxiv preprint doi: https://doi.org/10.1101/2020.08.24.20181248; this version posted January 11, 2021. The copyright holder for this preprint (which was not certified by peer review) is the author/funder, who has granted medRxiv a license to display the preprint in perpetuity.

It is made available under a CC-BY-NC-ND 4.0 International license .
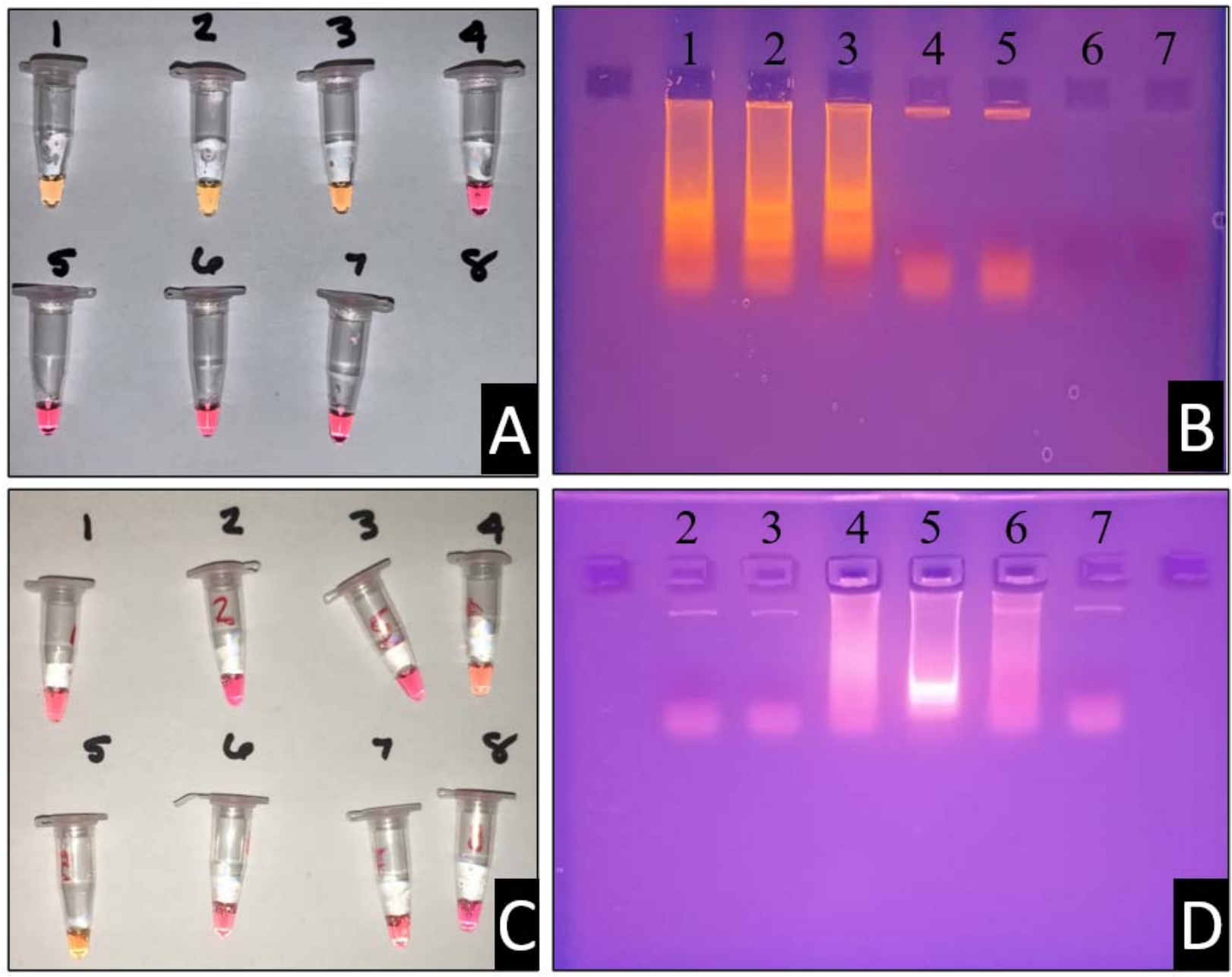

Figure 3. (A) Colorimetric reaction vessels for primer set 1.0 with the following reaction vessel containments: 1 - Primer w/DNA, 2 - Primer w/DNA, 3 - Primer w/DNA, 4 - Primer w/o DNA, 5 - Primer w/o DNA, 6 - No Primer/DNA, 7 - No Primer/DNA. (B) Ethidium bromide electrophoresis gel with samples of panel (A). The containments of each lane correspond with the reaction vessels as indicated. (C) Temperature gradient assay for LAMP primer set 1.0. Each of the reaction vessels (left) were also run with negative controls, not pictured. Reaction vessel numbers correspond with the ethidium bromide gel pictured in box (D), with the exception of vessel (1) and (8). From vessel (1) to (8), the temperature gradient follows the order (in ${ }^{\circ} \mathrm{C}$ ): $70.8,69.3,67.8,64.8,59.3$, 57.8, 56.3 and 54.8.

Future primer sets will be compared to these initial two primer candidates and put through a comparative 
medRxiv preprint doi: https://doi.org/10.1101/2020.08.24.20181248; this version posted January 11, 2021. The copyright holder for this preprint (which was not certified by peer review) is the author/funder, who has granted medRxiv a license to display the preprint in perpetuity.

It is made available under a CC-BY-NC-ND 4.0 International license .

DTV is a recent pathogen of interest and needs additional detection methods to monitor the long-term effects and spread. In the creation of a LAMP detection system point-of-care and field diagnostic, additional tools can be enacted to understand the spread of this virus. Primer set 1 was an excellent candidate for the detection of in vitro genetic material of the virus. Our second primer set was faulty but further improved primer design hypotheses and tactics. Further validation is currently being investigated for newer primer sets. Additional experimentation will be performed with RNA expression samples, tick samples spiked with DNA and RNA, and additional collaborations with state environmental agencies for tick testing. In addition to these tests, further experiments should be performed on isolates from varying regions in conjunction with further bioinformatic approaches. Through these efforts we hope to further promote mitigation tactics and reduce the number of infections in North America and beyond.

\section{Acknowledgments}

We would like to thank the Lebanon Valley College Biology Department for financially supporting this research, as well as the Beta Beta Beta Biological Honors Society National Research Grant for the 20192020 grant received for this project.

\section{Conflict of Interests}

The authors hereby state no conflict of interests.

\section{References}

Anupama KP, Chakraborty A, Karunasagar Iddya, Karunasagar Indrani, Maiti B. 2019. Loop-mediated isothermal amplification assay as a point-of-care diagnostic tool for Vibrio parahaemolyticus: recent developments and improvements. Expert Review of Molecular Diagnostics. 19(3):229-239. doi:10.1080/14737159.2019.1571913.

Artsob H, Karabatsos N, Kuno G, Tsuchiya KR, Chang GJ. 2001. Genomic sequencing of deer tick virus and phylogeny of powassan-related viruses of North America. The American Journal of Tropical Medicine and Hygiene. 65(5):671-676. doi:10.4269/ajtmh.2001.65.671.

Becherer L, Borst N, Bakheit M, Frischmann S, Zengerle R, von Stetten F. 2020. Loop-mediated isothermal amplification (LAMP) - review and classification of methods for sequence-specific detection. Anal Methods. 12(6):717-746. doi:10.1039/C9AY02246E.

Brackney DE, Brown IK, Nofchissey RA, Fitzpatrick KA, Ebel GD. 2010. Homogeneity of Powassan virus populations in naturally infected Ixodes scapularis. Virology. 402(2):366-371. doi:10.1016/j.virol.2010.03.035. 
medRxiv preprint doi: https://doi.org/10.1101/2020.08.24.20181248; this version posted January 11, 2021. The copyright holder for this preprint (which was not certified by peer review) is the author/funder, who has granted medRxiv a license to display the preprint in perpetuity. It is made available under a CC-BY-NC-ND 4.0 International license .

CDC. 2019. Powassan Virus. Center for Disease Control Division of Vector-Borne Diseases. https://www.cdc.gov/powassan/diagnostic-testing.html.

Chen Q, Yuan L, Wan J, Chen Y, Du C. 2014. Colorimetric detection of hepatitis E virus based on reverse transcription loop mediated isothermal amplification (RT-LAMP) assay. Journal of Virological Methods. 197:29-33. doi:10.1016/j.jviromet.2013.11.006.

Felsenstein J. 1985. Confidence limits on phylogenies: An approach using the bootstrap. Evolution 39:783-791.

Kumar S., Stecher G., Li M., Knyaz C., and Tamura K. 2018. MEGA X: Molecular Evolutionary Genetics Analysis across computing platforms. Molecular Biology and Evolution 35:1547-1549. Lamb LE, Bartolone SN, Tree MO, Conway MJ, Rossignol J, Smith CP, Chancellor MB. 2018. Rapid Detection of Zika Virus in Urine Samples and Infected Mosquitos by Reverse Transcription-LoopMediated Isothermal Amplification. Scientific Reports. 8(1). doi:10.1038/s41598-018-22102-5. [accessed 2018 Aug 22]. http://www.nature.com/articles/s41598-018-22102-5.

Lau Y-L, Lai M-Y, Teoh B-T, Abd-Jamil J, Johari J, Sam S-S, Tan K-K, AbuBakar S. 2015. Colorimetric Detection of Dengue by Single Tube Reverse-Transcription-Loop-Mediated Isothermal Amplification. Coffey LL, editor. PLOS ONE. 10(9):e0138694. doi:10.1371/journal.pone.0138694.

Luo L, Nie K, Yang M-J, Wang M, Li J, Zhang C, Liu H-T, Ma X-J. 2011. Visual Detection of High-Risk Human Papillomavirus Genotypes 16, 18, 45, 52, and 58 by Loop-Mediated Isothermal Amplification with Hydroxynaphthol Blue Dye. Journal of Clinical Microbiology. 49(10):3545-3550. doi:10.1128/JCM.00930-11.

Mitra D, Kimov IK, Waldeisen JR. 2019 Apr 9. Colorimetric Detection of Nucleic Acid Amplification. :32. https://patentimages.storage.googleapis.com/a8/99/cb/7d97af0ff74f58/US10253357.pdf.

Morozova OV, Dobrotvorsky AK, Livanova NN, Tkachev SE, Bakhvalova VN, Beklemishev AB, Cabello FC. 2002. PCR Detection of Borrelia burgdorferi Sensu Lato, Tick-Borne Encephalitis Virus, and the Human Granulocytic Ehrlichiosis Agent in Ixodes persulcatus Ticks from Western Siberia, Russia. Journal of Clinical Microbiology. 40(10):3802-3804. doi:10.1128/JCM.40.10.3802-3804.2002.

Nagamine K, Hase T, Notomi T. 2002. Accelerated reaction by loop-mediated isothermal amplification using loop primers. Molecular and Cellular Probes. 16(3):223-229. doi:10.1006/mcpr.2002.0415.

Pesko KN, Torres-Perez F, Hjelle BL, Ebel GD. 2010. Molecular epidemiology of Powassan virus in North America. Journal of General Virology. 91(11):2698-2705. doi:10.1099/vir.0.024232-0.

Roy BG, Ryndock E, Lappas CM. 2020 Oct 14. Utilizing loop $\square$ mediated isothermal amplification to detect the presence of ESCHERICHIA COLI $\square$ : An inquiry $\square$ driven undergraduate laboratory module. Biochem Mol Biol Educ.:bmb.21460. doi:10.1002/bmb.21460.

Shin D-S, Heo G-I, Son S-H, Oh C-S, Lee Y-K, Cha J-S. 2018. Development of an Improved LoopMediated Isothermal Amplification Assay for On-Site Diagnosis of Fire Blight in Apple and Pear. The Plant Pathology Journal. 34(3):191-198. doi:10.5423/PPJ.FT.03.2018.0055.

Solomon IH, Spera KM, Ryan SL, Helgager J, Andrici J, Zaki SR, Vaitkevicius H, Leon KE, Wilson MR, DeRisi JL, et al. 2018. Fatal Powassan Encephalitis (Deer Tick Virus, Lineage II) in a Patient With Fever and Orchitis Receiving Rituximab. JAMA Neurol. 75(6):746. doi:10.1001/jamaneurol.2018.0132. 
medRxiv preprint doi: https://doi.org/10.1101/2020.08.24.20181248; this version posted January 11, 2021. The copyright holder for this preprint (which was not certified by peer review) is the author/funder, who has granted medRxiv a license to display the preprint in perpetuity.

It is made available under a CC-BY-NC-ND 4.0 International license .

278 Tamura K. and Nei M. 1993. Estimation of the number of nucleotide substitutions in the control region of 279 mitochondrial DNA in humans and chimpanzees. Molecular Biology and Evolution 10:512-526.

281 Tavakoli NP, Wang H, Dupuis M, Hull R, Ebel GD, Gilmore EJ, Faust PL. 2009. Fatal Case of Deer Tick 282 Virus Encephalitis. New England Journal of Medicine. 360(20):2099-2107.

283 doi:10.1056/NEJMoa0806326.

284 Telford III S. 1997. A New Tick-borne Encephalitis-like Virus Infecting New England Deer Ticks, Ixodes 285 dammini. Emerg Infect Dis. 3(2):165-170. doi:10.3201/eid0302.970209.

286 Tomlinson J. 2008. Potential of LAMP for detection of plant pathogens. CAB Reviews: Perspectives in 287 Agriculture, Veterinary Science, Nutrition and Natural Resources. 3(066).

288 doi:10.1079/PAVSNNR20083066. [accessed 2019 Apr 21].

289 http://www.cabi.org/cabreviews/review/20083265890.

290 Wang D-G, Brewster J, Paul M, Tomasula P. 2015. Two Methods for Increased Specificity and 291 Sensitivity in Loop-Mediated Isothermal Amplification. Molecules. 20(4):6048-6059.

292 doi:10.3390/molecules20046048. 
Table 1. Primer candidate 1 sequences generated using the PrimerExplorerV5 software with respective loop primers (LF and LB).

297

\begin{tabular}{|c|l|l|l|l|}
\hline \multirow{2}{*}{ Primer } & Sequence (5' to 3') & Len. & $\begin{array}{l}5^{\prime} \\
\text { Pos. }\end{array}$ & $\begin{array}{l}3^{\prime} \\
\text { Pos. }\end{array}$ \\
\hline F3 & GTACCTCGACTTGCCAACC & 19 & 9580 & 9598 \\
\hline B3 & TGCGGGTAGGAAGTAGTGC & 19 & 9780 & 9798 \\
\hline \multirow{2}{*}{ FIP } & ATGTCCCGGAAAGGTTTGGACA- & 41 & $9647-$ & $9668-$ \\
\cline { 2 - 2 } \cline { 5 - 6 } & -TACGACCACTCACCTCTGC & & 9604 & 9622 \\
\hline \multirow{2}{*}{ BIP } & TGGGCATTCCTACACCCGCT- & 39 & $9691-$ & $9710-$ \\
\cline { 2 - 3 } & ACACTCGTCTTCCCGTGAA & & 9746 & 9764 \\
\hline LF & CTACCCAAACTGCTGCGTC & 19 & 9662 & 9680 \\
\hline LB & AGTCACCCCAAGTGTCGGAC & 20 & 9721 & 9740 \\
\hline
\end{tabular}

Table 2. Primer candidate 2 sequences generated using the PrimerExplorerV5 software with respective loop primers (LF and LB).

300

\begin{tabular}{|c|l|c|c|c|}
\hline Primer & Sequence (5' to 3') & Len. & $\begin{array}{l}5^{\prime} \\
\text { Pos. }\end{array}$ & $\begin{array}{l}3^{\prime} \\
\text { Pos. }\end{array}$ \\
\hline \multirow{2}{*}{ F3 } & TAAGGATGTGGGCGAGTGG & 19 & 9696 & 9714 \\
\hline B3 & TGGAAGTAGTTGAGGAGCCA & 20 & 9915 & 9934 \\
\hline \multirow{2}{*}{ FIP } & GAACGCCCATCCTTCATCACGA- & 41 & $9778-$ & $9799-$ \\
\cline { 2 - 2 } & TCACAGCCTGGGAAGAAGT & & 9731 & 9749 \\
\hline \multirow{2}{*}{ BIP } & ACGAGTGTCGCCAGGATGTG- & 40 & 9846 & 9865 \\
\cline { 2 - 3 } & CATACGCTTTGGACAGGCAG & & 9887 & 9906 \\
\hline \multirow{2}{*}{ LF } & TCATGGAAATGGTGTGAGCAGAAGG & 25 & 9751 & 9775 \\
\hline LB & ATGGAGCGTGCGGGAGACA & 19 & 9867 & 9885 \\
\hline
\end{tabular}

Table 3. Reagents added to reaction vessels to perform the colorimetric LAMP assay based on New England 302 Biolabs® protocol.

\begin{tabular}{|c|c|c|}
\hline & Experimental & Control \\
\hline $\begin{array}{l}\text { Warmstart }{ }^{\circledR} \quad \text { Colorimetric } \\
\text { LAMP } 2 \text { X Master Mix }\end{array}$ & $12.5 \mu \mathrm{L}$ & $\begin{array}{r}12.5 \mu \mathrm{L} \\
305\end{array}$ \\
\hline LAMP Primer Mix $10 X$ & $2.5 \mu \mathrm{L}$ & $2.5 \mu \mathrm{L}$ \\
\hline Target Genetic Sample & $1 \mu \mathrm{L}$ & N/A \\
\hline Molecular Grade $\mathrm{H}_{2} \mathrm{O}$ & $9 \mu \mathrm{L}$ & $10 \mu \mathrm{L}$ \\
\hline
\end{tabular}


medRxiv preprint doi: https://doi.org/10.1101/2020.08.24.20181248; this version posted January 11, 2021. The copyright holder for this preprint (which was not certified by peer review) is the author/funder, who has granted medRxiv a license to display the preprint in perpetuity.

It is made available under a CC-BY-NC-ND 4.0 International license.

Table 4. Codon-based Test of Neutrality for DTV sequences found in the United States.*

\begin{tabular}{|l|l|l|l|l|}
\hline & EU338403.1 & MG196295.1 & NC003687.1 & HM991145.1 \\
\hline EU338403.1 & --- & -2.5830 & -3.7536 & 4.4586 \\
\hline MG196295.1 & 0.0110 & --- & -15.7194 & -3.2327 \\
\hline NC003687.1 & 0.0003 & 0.0000 & --- & -3.2986 \\
\hline HM991145.1 & 0.0000 & 0.0016 & 0.0013 & --- \\
\hline
\end{tabular}

*The probability of rejecting the null hypothesis of strict-neutrality $(\mathrm{dN}=\mathrm{dS})$ (below diagonal) is shown. Values of $P$ less than 0.05 are considered significant at the 5\% level and are highlighted. The test statistic (dN - dS) is shown above the diagonal. $\mathrm{dS}$ and $\mathrm{dN}$ are the numbers of synonymous and nonsynonymous substitutions per site, respectively. The variance of the difference was computed using the analytical method. Analyses were conducted using the Nei-Gojobori method (Felsenstein J. 1985). This analysis involved 4 nucleotide sequences. All ambiguous positions were removed for each sequence pair (pairwise deletion option). There was a total of 3556 positions in the 